\title{
Peningkatan hasil belajar gerak dasar melempar melalui pendekatan bermain
}

\author{
Dessy Anggraeni ${ }^{1 *}$, S. Sutiyarsih ${ }^{2}$ \\ ${ }^{1}$ Universitas Negeri Yogyakarta. Jl. Colombo No.1, Yogyakarta 55281, Indonesia \\ ${ }^{2}$ SD Negeri Jarakan. Jalan Bantul Km.5, Kweni, Sewon, Bantul, Yogyakarta, Indonesia \\ ${ }^{*}$ Corresponding Author. Email:dessyapip113@gmail.com
}

\begin{abstract}
Abstrak
Penelitian ini bertujuan untuk meningkatkan hasil belajar variasi gerak dasar melempar dengan pendekatan bermain pada peserta didik kelas IV. Penelitian ini merupakan penelitian tindakan kelas yang berlangsung dua siklus. Subjek penelitian adalah peserta didik kelas IVA Sekolah Dasar Negeri Jarakan yang berjumlah 27 orang. Teknik pengumpulan data yang digunakan adalah tes unjuk kerja (praktik) individu peserta didik dan observasi pembelajaran. Hasil penelitian menunjukkan bahwa ada peningkatan hasil belajar peserta didik pada materi variasi gerak dasar melempar dengan pendekatan bermain. Hal ini terlihat dari hasil belajar pada siklus I yang menunjukkan 17 peserta didik mencapai ketuntasan sebesar $62,96 \%$ dengan nilai rata-rata 72 dan pada siklus II hasil belajar meningkat menjadi $88,89 \%$ dengan jumlah peserta didik yang mencapai ketuntasan sebanyak 24 dengan nilai rata-rata 79.
\end{abstract}

Kata kunci: variasi melempar, pendekatan bermain, hasil belajar.

\section{Improved results of learning basic motion throw through a play approach}

\begin{abstract}
This study aims to improve the learning outcomes of basic motion throwing variations with the playing approach on fourth-grade students. This research is a classroom action research that lasts two cycles. The research subjects were 27 students in class IVA of the State Primary School in Jarakan. Data collection techniques used are performance tests (practices) of individual students and learning observations. The results of the study indicate that there is an increase in student learning outcomes in material variations in basic motion throwing with a playful approach. This can be seen from the learning outcomes in the first cycle which showed 17 students achieved mastery of $62.96 \%$ with an average value of 72 and in the second cycle the learning outcomes increased to $88.89 \%$ with the number of students achieving 24 completeness with grades average 79.
\end{abstract}

Keywords: throw variation, approach to play, learning outcomes.

\section{PENDAHULUAN}

Pendidikan jasmani merupakan salah satu aspek dari proses pendidikan keseluruhan peserta didik melalui kegiatan jasmani yang dirancang secara cermat, yang dilakukan secara sadar dan terprogram dalam usaha meningkatkan kemampuan dan keterampilan jasmani dan sosial serta perkembangan kecerdasan (Abdullah, \& Manadji, 1994). Pembelajaran pendidikan jasmani di sekolah dasar bertujuan membantu peserta didik agar meningkatkan keterampilan geraknya. Selain itu agar muncul rasa senang dan mau berpartisipasi dalam berbagai aktifitas dalam bermain dengan meningkatkan keterampilan gerak, pemahaman kognitif, dan sikap positif terhadap aktivitas jasmani kelak akan menjadi manusia dewasa yang sehat, segar jasmani dan rohani serta kepribadian yang mantap.

Ruang lingkup dalam pendidikan jasmani yang diberikan dari jenjang sekolah dasar sampai sekolah lanjutan atas diantaranya: aktivitas pengembangan, aktivitas ritmik, aktivitas 
senam, aktivitas akuatik, kesehatan, pendidikan luar kelas serta aktivitas permainan dan olahraga. Salah satu kompetensi dasar untuk sekolah dasar kelas IV yaitu mempraktikkan variasi pola dasar jalan, lari, lompat, dan lempar melalui permainan/olahraga yang dimodifikasi dan atau olahraga tradisional. Melempar adalah suatu keterampilan manipulatif yang kompleks di mana satu atau dua tangan digunakan untuk melontarkan suatu objek menjauhi tubuh ke ruang tertentu.

Berdasarkan observasi terhadap pembelajaran yang telah dilakukan di SDN Jarakan, peneliti menemukan bahwa hasil belajar peserta didik kelas IVA pada materi variasi gerak dasar melempar masih rendah. Guru masih banyak menggunakan metode komando sehingga peserta didik masih kesulitan, cepat bosan dan kurang tertarik dalam mengikuti pembelajaran. Peserta didik cenderung menyukai olahraga yang bersifat game atau kompetisi, sehingga diperlukan metode pembelajaran ataupun modifikasi dalam pembelajaran. Salah satu pendekatan dalam pembelajaran yang digunakan dalam materi ini adalah pendekatan bermain. Pendekatan bermain digunakan peneliti sebagai salah satu alternatif yang digunakan dalam pemelajaran sehingga peserta didik akan merasa senang dan bersemangat dalam melakukan aktivitas pembelajaran dan intensitas latihan dapat meningkat. Dengan meningkatnya intensitas latihan, diharapkan hasil belajar variasi gerak dasar melempar peserta didik juga akan meningkat, sebagaimana tujuan dalam penelitian ini yaitu meningkatkan hasil belajar variasi gerak dasar melempar peserta didik kelas IVA SDN Jarakan.

\section{Belajar dan Hasilnya}

Uno (2011) berpendapat bahwa belajar merupakan suatu proses perubahan tingkah laku sebagai hasil dari latihan pengalaman individu akibat interaksi dengan lingkungannya. Perubahan-perubahan yang terjadi sebagai dari hasil perbuatan belajar seseorang dapat beupa kebiasaan-kebiasaan, kecakapan atau dalam bentuk pengetahuan, sikap dan keterampilan. Anni (2006) berpendapat bahwa hasil belajar merupakan perubahan perilaku yang diperoleh pembelajar setelah mengalami aktifitas belajar. Salah satu pertanda bahwa seseorang telah belajar adalah adanya perubahan tingkah laku dalam dirinya. Perubahan tingkah laku tersebut menyangkut baik perubahan yang bersifat pengetahuan (kognitif) dan keterampilan (psikomotor) maupun yang menyangkut nilai dan sikap (afektif). Hasil belajar dalam penelitian ini adalah perubahan yang mencakup aspek kognitif, afektif dan psikomotor yang dapat dilihat dari kemampuan peserta didik dalam melakukan variasi gerak dasar melempar.

\section{Faktor-faktor yang Mempengaruhi Hasil Belajar}

Hasil belajar mempunyai peranan penting dalam proses pembelajaran karena akan memberikan sebuah informasi kepada guru tentang kemajuan peserta didik dalam upaya mencapai tujuan-tujuan belajarnya melalui proses kegiatan belajar mengajar yang selanjutnya setelah mendapat informasi tersebut guru dapat menyusun dan membina kegiatan-kegiatan peserta didik lebih lanjut baik untuk individu maupun kelompok belajar. Menurut Munadi, faktor-faktor yang mempengaruhi hasil belajar antara lain: (1) Faktor Internal yaitu faktor yang timbul dari dalam diri peserta didik yang meliputi: faktor fisiologis, secara umum kondisi fisiologis seperti kesehatan yang prima, tidak dalam keadaan lelah, capek, dan faktor psikologis meliputi intelegensi (IQ), perhatian, minat, bakat, motif, motivasi dan daya nalar peserta didik, dan (2) Faktor Eksternal adalah faktor yang berasal dari luar diri peserta didik. Meliputi; lingkungan fisik, lingkungan sosial, kurikulum,sarana dan guru (Rusman, 2012).

\section{Pendidikan Jasmani Olahraga dan Kesehatan dan Pembelajarannya}

Pendidikan jasmani olahraga dan kesehatan merupakan bagian integral dari pendidikan secara keseluruhan, bertujuan untuk mengembangkan aspek kebugaran jasmani, keterampilan gerak, ketrampilan berfikir kritis, keterampilan sosial, penalaran, stabilitas emosional, tindakan moral, aspek pola hidup sehat dan pengenalan lingkungan bersih melalui aktivitas jasmani, olahraga dan kesehatan terpilih yang direncanakan secara sistematis dalam rangka mencapai pendidikan nasional. 
Kurikulum 2013 (K-13) adalah kurikulum yang berlaku dalam sistem pendidikan Indonesia. Dalam strusktur kurikulum 2013 sekolah dasar mata pelajaran PJOK memiliki alokasi waktu 4 jam pelajaran setiap minggu, dimana setiap jamnya adalah 35 menit. Mata pelajaran PJOK memiliki konten memberi sumbangan mengembangkan kompetensi gerak dan gaya hidup sehat, dan memberi warna pada pendidikan karakter bangsa. Pembelajaran PJOK dengan kearifan lokal akan memberi apresiasi terhadap multikultural yaitu mengenal permainan dan olahraga tradisional yang berakar dari budaya suku bangsa Indonesia dan dapat memberi sumbangan pada pembentukan karakter.

Berdasarkan Permendikbud Tahun 2016 nomor 24 lampiran 21 untuk materi yang di ajarakan pada kelas IV yaitu KD untuk kemampuan kognitif 3.3 Memahami variasi gerak dasar jalan, lari, lompat, dan lempar melalui permainan/olahraga yang dimodifikasi dan atau olahraga tradisional. Sedangkan untuk kemampuan psikomotor KD 4.3 Mempraktikkan variasi pola dasar jalan, lari, lompat, dan lempar melalui permainan/olahraga yang dimodifikasi dan atau olahraga tradisional. Sesuai dengan kompetensi dasar tersebut maka pembelajaran variasi pola dasar jalan, lari, lompat dan lempar dapat di modifikasi sesuai kemampuan peserta didik.

\section{Gerak Dasar Melempar}

Melempar adalah suatu keterampilan manipulatif yang kompleks di mana satu atau dua tangan digunakan untuk melontarkan suatu objek menjauhi tubuh ke ruang tertentu. Berdasarkan buku Penjas Orkes untuk siswa SD/MI kelas IV (Hadziq \& Musadad, 2016, p.72) pembelajaran yang dilaksanakan adalah variasi gerak dasar berjalan, variasi gerak dasar berlari, variasi gerak dasar melompat dan variasi gerak dasar melempar. Pada materi variasi gerak dasar melempar meliputi melempar bola berekor jauh, melempar bola berekor tinggi, dan melempar bola berekor ke sasaran adapun penjelasannya sebagai berikut: (1) Melempar bola berekor jauh adalah cara melempar untuk menempuh jarak yang jauh. Lemparan dilakukan dengan tenaga yang kuat. Gerakan lengan dari belakang dan lecutkan tangan ke depan untuk melepaskan bola, (2) Melempar bola berekor tinggi adalah cara melempar untuk lemparan tinggi. Lemparan dilakukan dengan tenaga yang kuat. Gerakan lengan dari bawah dan lecutkan tangan ke atas untuk melepaskan bola, (3) Melempar bola ke sasaran adalah cara melempar bola dengan memperhatikan sasaran lemparan. Lemparan dilakukan untuk dapat masuk atau mengenai sasaran yang telah di tentukan.

\section{Pendekatan Bermain}

Bermain merupakan salah satu setrategi dalam mangajarkan materi pendidikan jasmani yang diharapkan mampu mengembangkan peserta didik sesuai dengan tujuan pendidikan yang ingin dicapai. Kegiatan pembelajaran mata pelajaran pendidikan jasmani yang bernuansa permainan menyediakan pengalaman gerak yang komplit, sehingga membangkitkan motivasi pada siswa untuk berpartisipasi aktif dalam pembelajaran (Saputra, 2001). Permainan adalah cara bermain dengan mengikuti aturan-aturan tertentu yang dapat dilakukan secara individu maupun berkelompok guna mencapai tujuan tertentu. Pendekatan bermain adalah salah satu bentuk dari sebuah pembelajaran jasmani yang dapat diberikan di segala jenjang pendidikan. Porsi dan bentuk pendekatan bermain yang akan diberikan harus disesuaikan dengan aspek yang ada dalam kurikulum. Selain itu harus dipertimbangkan juga faktor usia, perkembangan fisik, dan jenjang pendidikan yang sedang dijalani.

\section{Karakteristik Peserta Didik Kelas IV}

Usia anak sekolah dasar adalah anak yang berusia 6-13 tahun. Perkembangan fisik anak yang terjadi pada masa ini menunjukkan adanya kecenderungan yang berbeda dibanding pada masa sebelumnya dan juga pada masa sesudahnya. Tingkatan kelas di sekolah dasar dapat dibagi dua menjadi kelas rendah dan kelas atas. Kelas rendah terdiri dari kelas satu, dua, dan tiga, sedangkan kelas-kelas tinggi sekolah dasar yang terdiri dari kelas empat, lima, dan enam. Adapun karakteristik pada kelas atas dapat dilihat dari berbagai perkembangan yang terjadi pada peserta didik diantaranya: (1) Perkembangan fisik, anak menjadi lebih tinggi, lebih berat, lebih kuat serta belajar berbagai keterampilan. Perubahan nyata terlihat pada sistem tulang, otot dan keterampilan gerak, perkembangan motorik menjadi 
lebih halus dan lebih terkoordinasi; (2) Perkembangan kognitif, anak menggunakan operasi mental untuk memecahkan masalah-masalah yang aktual dan menggunakan kemampuan mentalnya untuk memecahkan masalah yang bersifat konkret, (3) Perkembangan afektif, pada usia ini berupa perkembangan moral yang ditandai dengan kemampuan anak untuk memahami aturan, norma dan etika yang berlaku di masyarakat, dan perkembangan tingkah laku sosial yang ditandai dengan interaksi dengan orang lain serta dalam hal perkembangan emosi

\section{METODE}

Penelitian ini merupakan penelitian tindakan kelas (Classroom Action Research) yang dilakukan secara kolaboratif. Arikunto \& Suhardjono (2009) menyatakan bahwa model penelitian ini menggunakan 4 tahapan, yaitu terdiri dari planning (menyusun rancangan tindakan), acting (pelaksanaan tindakan), observing (pengamatan), reflecting (refleksi).

Penelitian tindakan kelas ini di laksankan di SDN Jarakan beralamat di Jl. Bantul KM. 5 Kweni, Panggungharjo, Sewon, Bantul, Daerah Istimewa Yogyakarta. Penelitian ini dilaksanakan pada bulan Oktober-November 2017. Subjek penelitian ini adalah peserta didik kelas IVA berjumlah 27 peserta didik. Personil yang terlibat dalam penelitian kolaboratif ini adalah guru pembimbing PPL PPG SM3T UNY dan rekan PPL PPG SM3T UNY.

Teknik pengumpulan data dalam penelitian ini adalah teknik tes dan non tes. Tes yang digunakan adalah tes unjuk kerja/tes praktik variasi gerak dasar melempar sedangkan non tes berupa pengamatan pembelajaran guru dan peserta didik selama proses pembelajaran. Instrumen penelitian yang digunakan adalah rubrik penilaian unjuk kerja/praktik dan lembar observasi. Rubrik penilaian unjuk kerja/praktik variasi gerak dasar melempar yaitu berupa lembar penilaian dengan tiga variasi gerak dasar melempar yang dipraktikkan peserta didik yaitu melempar bola berekor jauh, melempar bola berekor tinggi dan melempar bola berekor ke sasaran. Masing-masing gerak dasar memiliki empat kriteria penilaian. Sedangkan lembar observasi diisi oleh kolaborator dengan melakukan pengamatan dan pencatatan mengenai pelaksanaan pembelajaran dengan memberikan (checklist) dalam lembar observasi dengan pilihan "ya atau tidak".

Hasil tes unjuk kerja/praktik yang dilaksanakan pada akhir setiap siklus dihitung rataratanya dan dihitung ketuntasan belajar secara klasikal dalam bentuk persen (\%). Hasil kemudian dikategorikan dalam batas-batas penilaian yang berdasarakan pada ketuntasan peserta didik. Hasil tes pada akhir siklus I dan siklus II dibandingkan dengan data awal atau data pratindakan. Sedangkan data observasi yang diperolehdiamati dan disimpulkan kemudian disajikan secara deskriptif kualitatif sebagai hasil pengamatan proses pembelajaran.

\section{HASIL DAN PEMBAHASAN}

Hasil tes terbagi atas tiga bagian yaitu pratindakan, siklus I dan siklus II berupa hasil belajar variasi gerak dasar melempar.

\section{Deskripsi Data Hasil Pra-tindakan}

Hasil tes pratindakan merupakan pretes peserta didik kelas IVA SDN Jarakan dalam melakukan variasi gerak dasar melempar sebelum diberi tindakan. Tes ini dilakukan dengan tujuan untuk mengetahui kemampuan awal peserta didik kelas IVA. Berikut data hasil pratindakan:

Tabel 1. Data Hasil Pratindakan

\begin{tabular}{cccc}
\hline No & Kategori & Jumlah Peserta Didik & Persentase \\
\hline 1. & Tuntas & 7 & $25,93 \%$ \\
2. & Tidak Tuntas & 20 & $74,07 \%$ \\
& Jumlah & 27 & $100 \%$ \\
\hline
\end{tabular}

Berdasarkan Tabel 1 menunjukkan bahwa banyaknya peserta didik yang tuntas dalam melakukan variasi gerak dasar melempar sesuai kriteria penilaian adalah 7 peserta didik 
dengan persentase 25,93\%, sedangkan 20 peserta didik dengan persentase $74,07 \%$ belum tuntas.

\section{Deskripsi data siklus I}

Siklus I dilaksanakan dalam satu kali pertemuan dengan alokasi waktu 4x35 menit. Siklus I terdiri dari empat tahapan yaitu perencanaan, tindakan, pengamatan dan refleksi. Pada tahap perencanaan, kegiatan yang dilakuakan adalah berdiskusi dengan guru pembimbing mengenai belum maksimalnya hasil belajar variasi gerak dasar melempar pada peserta didik kelas IVA di SDN Jarakan. Kegiatan selanjutnya adalah menyusun rencana pelaksanaan pembelajaran (RPP), menyiapkan sarpras yang dibutuhkan dalam pembelajaran dan meminta bantuan guru pembimbing dan rekan PPL sebagai kolaborator. Pada tahap tindakan, guru melaksanakan pembelajaran sesuai RPP yang telah dibuat dengan materi variasi gerak dasar melempar yang terdiri dari melempar bola berekor jauh, melempar bola berekor tinggi dan melempar bola berekor ke sasaran dengan pendekatan bermain. Adapun jalannya proses pembelajaran adalah sebagai berikut: (1) peserta didik dibariskan, berdoa, presensi dan guru menyampakan garis besar materi yang akan diajarkan, (2) pemanasan dengan permainan "menandai wilayah", (3) mengamati, peserta didik mengamati gambar dan demonstrasi guru tentang materi variasi gerak dasar melempar, (4) menanya, peserta didik bersama guru merumuskan pertanyaan sesuai materi pembelajaran, (5) mencoba, peserta didik mempraktikkan permainan melempar bola berekor jauh ke daerah nama hewan dalam hutan, permaian "tangkap kardus" yaitu melempar bola setinggi-tingginya dan teman lain yang akan menangkap dengan kardus, permainan selanjutnya yaitu melempar bola berekor ke sasaran kun dan botol, masing-masing kelompok menghitung jumlah poin yang di dapatkan, (6) mengasosiasi, peserta didik mempraktikkan permainan "throw in throw out", (7) mengomunikasikan, peserta didik bersama guru membuat simpulan dan umpan balik pembelajaran, (8) peserta didik melakukan pendinginan dengan permainan "putar bola" sambil bernyanyi. Pada tahap pengamatan, dilaksanakan selama proses pembelajaran berlangsung dan mengungkapkan berbagai aktivitas guru dan peserta didik dalam pembelajaran. Pada tahap refleksi, peneliti dan kolaborator bersama-sama membahas tindakan yang telah dilakukan dan mengungkapkan hal-hal yang perlu dilakukan perbaikan. Data hasil belajar siklus I dapat dilihat pada Tabel 2.

Tabel 2. Data Hasil Belajar Siklus I

\begin{tabular}{cccc}
\hline No & Kategori & Jumlah Peserta Didik & Persentase \\
\hline 1. & Tuntas & 17 & $62,96 \%$ \\
2. & Tidak Tuntas & 10 & $37,04 \%$ \\
& Jumlah & 27 & $100 \%$ \\
\hline
\end{tabular}

Berdasarkan Tabel 2 menunjukkan hasil belajar peserta didik meningkat dibandingkan dengan hasil pratindakan. Peserta didik yang sudah tuntas sebanyak 17 peserta didik dengan persentase $62,96 \%$, sedangkan yang tidak tuntas sebanyak 10 peserta didik dengan persentase 37,04 . Namun, tingkat ketuntasan belajar secara klasikal belum mencapai $75 \%$.

\section{Deskripsi data siklus II}

Siklus II dilaksanakan sebagai upaya perbaikan pada siklus I dan dilaksanakan dengan empat tahapan yaitu perencanaan, tindakan, pengamatan dan refleksi. Pada tahap perencanaan, membuat perencanaan dengan perbaikan pada siklus I, seperti membuat RPP dengan permainan yang lebih menarik, mempersiapkan kartu tugas kelompok, guru yang membagi peserta didik dalam kelompok, mengefektifkan penggunaan lapangana dan waktu, serta guru lebih rinci dalam menjelaskan materi dan peraturan permainan. Pada tahap tindakan, guru melaksanakan pembelajaran sesuai RPP yang telah dibuat. Adapun jalannya pembelajaran adalah, (1) guru mengkondisikan peserta didik, membariskan, berdoa, memberi salam menyampaiakan apersepsi dan materi lanjutan, (2) melaksanakan pemanasan dengan permainan "the flash", (3) mengamati, peserta didik mengamati gambar dan demonstrasi guru tentang materi variasi gerak dasar melempar, (4) menanya, peserta didik bersama guru merumuskan pertanyaan dengan memfokuskan pada posisi tangan, posisi kaki dan cara melempar, (5) mencoba, peserta didik mempraktikkan gerakan melempar bola berekor jauh 
ke zona angka dari 1,2,3 dan 4, peserta didik mempraktikkan gerak dasar melempar bola berekor tinggi dengan permainan "tangkap cone" peserta didik melempar bola setinggitingginya kemudian menangkap kembali menggunakan cone, peserta didik mempraktikkan gerak dasar melempar bola berekor ke sasaran simpai yang digantung, kemudian masingmasing kelompok menghitung poin yang di dapatkan, kelompok yang mendapat poin terbanyak adalah pemenangnya, (6) mengasosiasi, peserta didik mempraktikkan permainan "boi-boinan" yang dimodifikasi menggunakan botol sebagai sasaran, (7) mengomunikasikan, peserta didik membuat simpulan dan umpan balik materi variasi gerak dasar melempar, (8) peserta didik melakukan pendiginan dengan permainan"ular naga". Pada tahap pengamatan, selama proses pembelajaran berlangsung perbaikan dalam pembelajaran sudah dilaksanakan seperti guru sudah menyampikan materi dan perturan permainan dengan jelas, guru juga sudah memberikan kesempatan bertanya sehingga peserta didik aktif. Pada tahap refleksi, mendiskusikan hasil pengamatan dan perbaikan yang telah dilakukan. Dalam refleksi menunjukkan bahwa proses pembelajaran lebih meningkat serta peserta didik lebih aktif, bersemangat dalam mengikuti pembelajaran dengan berbagai permainan. Sehingga hasil belajar variasi gerak dasar melempar mengalami peningkatan. Data hasil belajar siklus II dapat dilihat pada Tabel 3.

Tabel 3. Data Hasil Belajar Siklus II

\begin{tabular}{cccc}
\hline No & Kategori & Jumlah Peserta Didik & Persentase \\
\hline 1. & Tuntas & 24 & $88,89 \%$ \\
2. & Tidak Tuntas & 3 & $11,11 \%$ \\
& Jumlah & 27 & $100 \%$ \\
\hline
\end{tabular}

Berdasarkan Tabel 3 hasil belajar pada siklus II mengalami peningkatan dibandingkan siklus I. Banyaknya peserta didik yang tuntas adalah 24 peserta didik dengan persentase sebesar $88,89 \%$ sedangkan yang tidak tuntas sebanyak 3 peserta didik dengan persentase sebesar $11,11 \%$. Pada siklus II tingkat ketuntasan hasil belajar peserta didik secara klasikal sudah lebih dari $75 \%$ dari keseluruhan peserta didik. Sehingga penelitian ini berhenti pada siklus II.

Hasil penelitian pembelajaran variasi gerak dasar melempar dengan pendekatan bermain pada peserta didik kelas IVA SD N Jarakan dari hasil belajar pratindakan, siklus I dan siklus II disajikan pada Tabel 4.

Tabel 4. Data Peningkatan Hasil Belajar Pratindakan, Siklus I dan Siklus II

\begin{tabular}{llccc}
\hline No. & \multicolumn{1}{c}{ Aspek } & Pratindakan & Siklus 1 & Siklus 2 \\
\hline 1 & Nilai Rata-Rata & 65 & 72 & 79 \\
2 & Persentase Ketuntasan & 25,93 & 62,96 & 88,89 \\
3 & Jumlah Peserta Didik & 7 & 17 & 24 \\
\hline
\end{tabular}

Peningkatan hasil belajar variasi gerak dasar melempar dengan pendekatan bermain pada peserta didik kelas IVA SD N Jarakan ditandai dengan peningkatan nilai rata-rata peserta didik. Nilai rata-rata peserta didik pada kondisi awal sebesar 65 dengan persentase ketuntasan sebesar $25,93 \%$ dengan jumlah peserta didik yang tuntas adalah 7 peserta didik. Kondisi tersebut mengalami peningkatan nilai rata-rata peserta didik pada siklus I yaitu sebesar 72 dan persentase ketuntasan sebesar $62,96 \%$ dengan jumlah peserta didik yang tuntas adalah 17 peserta didik. Namun, peningkatan tersebut masih belum mencapai target yang ditetapkan sebelumnya. Kemudian setelah melanjutkan ke siklus II nilai rata-rata hasil belajar variasi gerak dasar melempar peserta didik kelas IVA kembali mengalami peningkatan sebesar 79 dengan persentase ketuntasan sebesar $88,89 \%$ dengan jumlah peserta didik yang tuntas adalah 24 peserta didik. Hal tersebut menunjukkan bahwa jumlah peserta didik yang mencapai KKM sudah lebih dari $75 \%$ sehingga penelitian dihentikan pada siklus II. Proses pembelajaran variasi gerak dasar melempar dengan pendekatan bermain pada peserta didik kelas IVA SD $\mathrm{N}$ Jarakan berlangsung dinamis dan menyenangkan, serta peserta didik mendapat pengalaman baru dengan berbagai permainan serta meningkatkan kerjasama, tanggung 
jawab, percaya diri, dan semangat di setiap pertemuan. Peserta didik aktif melaksanakan tugas dan mengamati gerakan melempar dan saling diskusi dengan teman.

\section{SIMPULAN}

Hasil penelitian menunjukkan bahwa pendekatan bermain dapat meningkatkan hasil belajar variasi gerak dasar melempar pada peserta didik kelas IVA SD N Jarakan. Persentase peserta didik yang mencapai KKM lebih dari 75\% yaitu $88,89 \%$. Pendekatan bermain dapat dijadikan sebagai salah satu alternatif dalam pembelajaran PJOK dan memiliki potensi untuk dikembangkan agar memberikan pengalaman gerak yang lebih luas dan lebih bervariasi. Serta dapat meningkatkan kualitas pembelajaran dan hasil belajar peserta didik dalam materi variasi gerak dasar melempar.

\section{DAFTAR PUSTAKA}

Abdullah, A., \& Manadji, A. (1994). Dasar-Dasar Pendidikan Jasmani. Jakarta: Departemen Pendidikan dan Kebudayaan.

Anni, C.T. (2006). Psikologi Belajar. Semarang: UPT MKK UNNES.

Arikunto, S., \& Suhardjono, S. (2009). Penelitian tindakan kelas. Jakarta: PT Bumi Aksara.

Hadziq, K., \& Musadad, A. (2016). Penjas orkes untuk siswa SD/MI Kelas IV. Jakarta: Yrama Widya.

Permendikbud No. 24 Tahun 2016 tentang Kompetensi Inti dan Kompetensi Dasar Pelajaran pada Kurikulum 2013.

Rusman. (2012). Belajar dan Pembelajaran Berbasis Komputer Mengembangkan Profesionalisme Guru Abad 21. Bandung: ALFABETA.

Saputra, Y. M. (2001). Dasar-dasar Keterampilan Atletik Pendekatan Bermain. Jakarta: Depdikbud.

Uno, B. H. (2011). Orientasi Baru dalam Psikologi Pembelajaran. Jakarta: Bumi Aksara 